\title{
기업의 글로벌 CSR 현황과 공유가치창출(CSV)
}

목 차

1. 서론: 문제의식

2. $\mathrm{CSR}$, 글로벌 $\mathrm{CSR}$ 을 보는 시각과 적용 범위

3. 글로벌 CSR 발전단계와 현황

4. Global CSR과 CSR-PPP

5. 글로벌 $\mathrm{CSR}$ 과 $\mathrm{CSV}$

6. 결론과 시사점

\section{1. 서론: 문제의식}

기업의 사회적 책임(Corporate Social Responsibility: CSR)에 대한 관심과 그 중요성에 대한 강조는 기업의 이윤추구 활동과 사회적 환경이 상호 영향을 주고받고 있음을 전제로 한다. 특히 사회복지, 사회보호시스템의 구축 등 사회적 환경의 개선이 궁극적으로는 기업의 영리활동 극대화로 이어질 수 있으며, 이는 다시 기업의 글로벌 CSR 전략 수준을 한 단계 끌어올리는 근거로 작용한다는 선순환 과정이 강조된다. 이러한 문제의식은 개발협력의 과정에서 더욱 뚜렷해질 수 있다. 즉, 개발협력 과정에서의 $\mathrm{CSR}$ 은 개발재원 확대 측면에서도 단순한 시혜적, 법적 책임의 이행 단계를 넘어 보다 더 전략적으로 해석되어야 하는 요인으로 인식된다. 또한 글로벌 CSR의 발전단계를 설정하고 해당 프레임워크로 기업의 글로벌 CSR 사업 현황을 분석, 진단하며 이를 통해 보다 더 높은 차원의 글로벌 CSR 단계로 나가려는 기업의 노력도 결국 이러한 문제의식에 대한 동의에 바탕을 두고 있다. 한편, 최근 활발히 논의되고 있는 공유가치창출(Creating Shared Value: CSV) 논의도 결국 이러한 글로벌 CSR 발전단계 논의와 연장선에 있으며, 개발협력의 과정에서도 CSV 원리는 매우 주목받고 있는 추세이다. 결국 CSR, CSV의 강조는 개발협력을 위한 보다 효과적이고 지속적인 전략 형성과 개발재원 확대의 측면에서 유효성을 가진다. 
이러한 배경과 문제의식을 바탕으로, 본 글에서는 개발협력의 맥락에서 (1) CSR과 글로벌 CSR에 대한 분석 시각과 적용 범위를 살펴보고, (2) 글로벌 CSR의 발전단계와 유형화 논의를 정리하며, (3) 글로벌 CSR 관련 국내외 기업의 지속가능한 성장 규준과 사회공헌활동 현황을 정리하였다. 이를 위해 UN Global Compact의 Corporate Sustainability Report와 전경련의 국내기업 사회공헌 백서 (Corporate Community Relations White Book)의 주요 결과를 살펴보았다. (4) 또한 글로벌 CSR 의 다양한 파트너십 형성과 성과를 CSR-PPP 사업 사례를 중심으로 소개하였으며, (5) 마지막으로 최근 새로운 지향점으로 떠오르고 있는 '공유가치창출(CSV)'에 대한 개념규정 및 형성방법과 관련된 논의를 정리하였다.

결국 이러한 분석은 개발협력과정에서 향후 바람직한 글로벌 CSR 전략의 방향성 모색과 개발협력 과정에서 기업의 글로벌 CSR이 궁극적으로 지향해야 하는 가치를 일깨우며, 최근 개발협력 지형에서 활발히 논의되고 있는 CSV 개념의 올바른 정립과 사업적용에도 일조하고자 함이다.

\section{2. $\mathrm{CSR}$, 글로벌 $\mathrm{CSR}$ 을 보는 시각과 적용 범위}

$\mathrm{CSR}$ 을 보는 시각과 정의는 다양하게 이루어지고 있지만, 기업의 이해관계와 사회적 활동과의 연계성을 나타내는 의미로서의 CSR은 "사회가 기업에 대하여 가지고 있는 경제적, 법률적, 윤리적 및 재량적 기대”라고 정의되고 있다(Carroll, 1979). 이러한 초기 개념을 넘어 2000년 이후 CSR은 '장기적인 기업 경쟁력 제고를 위한 전략적 가치'라는 인식이 확대되고 있다. 이는 법률적, 윤리적 책임을 넘어 기업 성장의 핵심전략으로 CSR이 자리 잡고 있음을 의미한다.

CSR에 대한 인식의 확대는 관련 연구를 통해서도 확인되고 있다. Pava·Krausz(1996) 그리고 Stanwick(1998) 등은 기업을 대상으로 한 실증연구를 통해 CSR과 재무성과 간의 긍정적인 연관성이 있음을 밝혀냈다. 한편 Brown · Dacin(1997)은 CSR이 기업과 기업이 생산해 내는 제품 브랜드 평가에 크게 영향을 미친다는 것을 보여주었다. 더 나아가 Bhattacharya(2008), Korschun(2011) 등에 따르면 CSR은 '기업과 소비자 간의 관계를 향상시킬 수 있는 중요자산'이라고 정의하기도 했다. 이종서(2010)는 기업의 사회적 책임(CSR)과 EU국가의 도시 간 · 부문별 협력정책과의 연관성에 대해 연구했다. 그는 기업의 사회적 책임의 개념을 '사회공헌' 이나 '투명경영' 등 협의적인 개념으로 접근하는 것을 지양하고, '기업이 경제적, 환경적, 윤리적 책임을 다함으로써 기업의 지속 가능한 성장을 유도하는 것' 으로 정의했다. 또한 사회적 책임의 수행 배경을 이해당사자 간의 단기적, 자율적 거래관계가 아닌 장기적이고도 가치 중심적인 기업전략으로 파악했다. 이러한 논의에 따르면 기업이 사회적 책임을 수행하는데 드는 비용은 투자로 인식되어야 하며, 이를 통해 기업경쟁력 강화도 이루어질 수 있다는 분석이다. 실제로 $\mathrm{EU}$ 국가에서는 열린 단일시장의 출현에 발맞추어 기업의 사회적 책임이 정책적으로 더욱 엄격히 규정되고 규범화되고 있는 상황이다. 
또한 주목할 만 한 점은 2000년대 중반 미국기업의 기업 윤리문제와 기업파산 상황이 대두되면서, 미국 기업과 학계는 CSR을 기업의 지속가능성(corporate sustainability)문제와 접목시켜야만 하는 전략적 개념으로 이해하기 시작했다. 변선영 · 김진욱(2011)은 CSR을 '전통적 CSR'과 '전략적 CSR(Strategic Corporate Social Responsibility)'1)로 구분하고 전략적 CSR활동이 전통적 CSR 활동보다 기업성과에 더 큰 긍정적 영향을 미치는 알아보고자 했다. 연구결과 전략적 $\mathrm{CSR}$ 활동이 기업의 사회적, 재무적 성과 영역 모두에서 전통적 CSR 활동보다 더 크고 긍정적인 영향을 주는 것으로 나타났다. 또한 전략적 $\mathrm{CSR}$ 활동이 기업의 이익창출, 사회공헌, 사회혁신의 책임활동 등에도 매개효과를 갖는 것으로 확인되었다. 이는 기업이 CSR을 기업의 홍보이미지 제고를 위한 비용정도로 간주하던 이전 경향에서 벗어나 이제는 '전략적 투자활동'으로 간주해야 함을 의미한다. 이들 비교분석의 가설은 Poter and Kramer(2006)의 연구에 바탕을 두는데, Poter and Kramer는 ‘경쟁우위와 CSR'이라는 연구를 통해 '전략적 CSR은 단기적 소모비용이 아닌 기업의 장기적인 기회, 혁신, 경쟁우위의 원천 자원'이라고 주장 한다(김성규, 2011: 7-8).

$\mathrm{CSR}$ 을 세 가지 시각에서 접근, 이해하기도 한다. 첫째, 기업의 이윤추구 우선론에 바탕을 둔 CSR 이해이다. 이러한 맥락에서 보면 CSR은 기업 본연의 목적인 이익확대를 저해하는 요인이다. 이는 기업이 공공영역인 '사회적 과제'를 처리할 능력도 이유도 없다는 점이 강조되며, '소극적 CSR' 관점이라고도 표현된다. 둘째, 기업외부 환경, 즉 사회 환경의 발전이 기업발전에도 유리하다는 접근이며, 이는 '자발적 CSR' 단계로 표현된다. 즉, 사회문제의 발생은 기업 활동에 부정적 영향을 초래하므로 기업도 CSR을 통해서 사회문화적 규범을 준수할 필요성이 있다는 것이다. 하지만 이 단계도 장기 전략적 관점으로서의 CSR 수행과는 거리가 있다. 세 번째는 전략적 CSR 단계 혹은 사회적 투자로서의 CSR 접근이다. 이는 사회적 투자론(Social Investment Theory)의 관점에서 기업의 이윤과 CSR은 분리된 것이 아닌 공동가치창조(CSV)라는 목표를 향해 하나로 수렴되는 '상호 전략적 동반자 관계'라고 할 수 있다(곽재성, 2012:16).

한편 세계화의 진전, 개발협력에서 기업의 사회적 책임 강조 등으로 인해 글로벌 CSR의 중요성 또한 강조되고 그 전략은 진화되어 왔다. 글로벌 시장의 확대, 개발 협력의 진전이라는 환경적 변화는 이미 국경을 넘는 기업의 사회적 책임이 보다 강조될 수밖에 없는 상황임을 말해주고 있다. 이는 기업이 세계시장, 특히 개도국에서 사회적, 윤리적 책임의 준수 여부가 법적 책임을 넘어 기업 생존과도 직결되는 사례를 통해서도 입증되고 있다. 기업의 글로벌 시민정신(Global Corporate Citizenship)이라는 개념이 강조되는 것도 이러한 맥락에서다. 한마디로 글로벌 CSR은 환경에 대한 소극적 대응을 넘어 기업 경영 활동에 전략적 · 적극적으로 반영되고 있다. 즉, 글로벌 CSR에서 강조되어 왔던 책임 요소인 경제적, 법적, 윤리적, 자선적 책임을 바탕으로 하여, CSR의 당위성, $\mathrm{CSR}$ 의 수준 설정, $\mathrm{CSR}$ 가이드라인 설정을 통해, $\mathrm{CSR}$ 이 결국 경영의사 결정과정과 기업사명, 경영전략, 현지화 전략에 적극 반영되고 있다는 점이다. 이러한 기업의 글로벌 CSR 전략이 개발협력 과정에 유용하고도 조화롭게 반영될 수 있게 하는 것은 우리에게 주어진 과제이자 도전이다.

1) SCSR(Strategic Corporate Social Responsibility)은 2001년 Porter and Kramer에 의해 분석 개념으로 제시 된 후 최근 사회적 기업 연구 영역에서 큰 관심을 받고 있는 개념인데, '기존의 전통적 CSR을 기업의 지속가 능성이나 경쟁우위를 확보하기 위한 자원으로 보다 적극적으로 활용하는 활동'으로 정의할 수 있다. 


\section{〈그림 1〉 전략적 글로벌 CSR 과정}

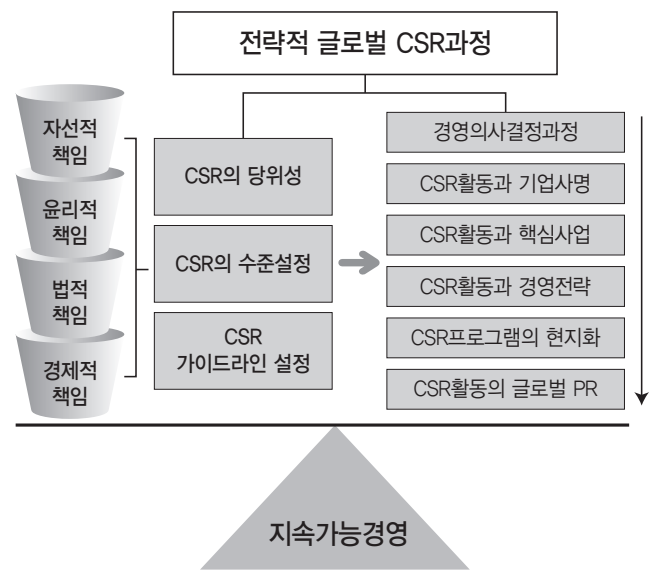

출처: 홍성헌, 2009:53

다음으로, 개발협력 관련 글로벌 CSR의 적용범위에 대해서 살펴보면, 우선 민간기업의 개발협력 과정 참여 활성화 과정과 '개발을 위한 비즈니스(B4D: Business for Development)' 프로그램 도입에 글로벌 CSR 개념이 적용 될 수 있다. 민간기업 활성화는 일자리 창출 논의로 연결되며, 기업의 사회적 책임(CSR)과 개도국 일자리 창출 관련 사업은 현재 국제사회와 개발협력 국제기구 등이 주목하고 있는 주제이다. 개도국 내 '사회적 기업' 형성 지원과 이를 통한 일자리 창출 논의도 같은 맥락에서 이루어진다.

또한, 글로벌 $\mathrm{CSR}$ 은 일자리 창출 관련, 일자리의 법적 규준, 가치 등은 Global CSR 개념과 긴밀한 관계에 놓여 있다. 이렇게 볼 때 글로벌 CSR은 이른바 '사회적 경제'의 확대와 이른바 '사회적 일자리')를 만들어내는 중요한 기제 중 하나인 것이다. 즉, 기업의 CSR을 통해 보다 사회적인 일자리가 창출될 가능성이 높으며, 동시에 사회적 일자리의 확대는 CSR의 가치를 보다 굳건히 한다. 결국 이러한 선순환은 기업의 지속가능한 발전에도 긍정적인 요인으로 작용한다.

한편, $\mathrm{OECD}$ 는 $\mathrm{CSR}$ 을 다음 여섯 가지 영역으로 나누어 강조하고 있는데, 첫째, 공정한 경쟁, 둘째, 법률준수, 셋째, 차별 없는 고용, 넷째, 노동권 보호, 다섯째, 환경보호, 여섯째, 기업시민권이 그것이다. 또한 $\mathrm{OECD}$ 는 이미 1970 년대 중반 이후 다국적 기업의 $\mathrm{CSR}$ 관련 규범을 채택, 발전시켜왔다. 1976년 '국제투자와 다국적 기업에 관한 OECD 선언(OECD Declaration on

2) '사회적 일자리'란 사회 공익적으로는 유용하다고 판단되지만 수익성이 낮아 민간 기업이 참여하기 어려워 활성화되지 못하는 일자리이다. 따라서 주로 정부의 예산지원이나 비영리단체에 의해 창출된다. 사회적 일자 리로는 저소득 근로자 및 빈곤층 자녀 돌봄, 장애인 교육원, 저소득층 노인이나 장애인을 위한 도우미 등을 들 수 있다. 애초 사회적 일자리라는 개념은 유럽 저소득층의 장기 실업 문제가 대두되기 시작한 1980년대 에 생긴 것으로, 개념적으로 사회적 기업(Social Enterprise), 사회적 경제(Social Economy) 등의 용어와 관련 있다. 이러한 맥락에서 사회적 일자리 창출은 개도국 빈곤층 - 취약계층에게 일자리를 제공하고, 동시에 이를 통해 지역사회의 삶의 질을 개선하는 이중의 효과를 지닐 수 있다고 판단되며, 특히 근로능력 미약집단을 대 상으로 근로활동을 촉진하기 위해 정책적으로 필요한 개념이다. 
international Investment and Multinational Enterprises)'을 통해 '다국적 기업 가이드라인' 이라는 규범을 채택하면서 정보공개의무, 고용 및 노사관계, 환경문제, 뇌물, 조세 등의 분야에서 다국적기업의 사회적 책임을 규정했다.

\section{3. 글로벌 CSR 발전단계와 현황}

\section{1 글로벌 CSR 발전 단계}

글로벌 CSR 단계를 그 책임의 정도에 따라 분류하기도 한다. 즉, 가장 기업의 존재 근거가 되는 글로벌 경제적 책임, 최소한으로 기업이 지켜야하는 책임인 글로벌 법적, 윤리적 책임, 그리고 기업이 능동적으로 최대한 지켜야 하는 글로벌 자선적 책임의 단계가 그것이다. 그런데 이러한 구분은 기업의 적극성을 기준으로 제시하고 있는 단계로, 글로벌 CSR을 전략적인 관점에서 보면 CSR을 여전히 시혜적 - 자선적 관점으로 보고 있다는 점에서 일정정도 한계를 가진다. 한편, Global CSR의 단계를 발전 정도와 전략에 따라 법규준수단계, 산발적 추진단계, 전략적 단계, 사회적 지지단계로 나누기도 하는데, 이러한 틀은 결국 기업의 Global CSR이 해당 사업 지역 사회에서 어느 정도 지지를 획득하고 있는가를 기준으로 그 단계를 분석하고자 함이다.

보스톤 대학의 기업시민정신연구소(Corporate Citizenship Center: CCC)는 글로벌 CSR 발전 단계를 설정, 분석하는데 있어 기초(Elementary), 관여(Engaged), 혁신(Innovative), 통합 (Integrated), 전환(Transforming) 모델의 개념을 제시하고 있다. ${ }^{3)}$ 기초, 관여 모델은 상대적으로 기업 CSR의 기본 역량과 의지 측면에서 가장 낮은 단계로 할 수 있다. 혁신(innovative) 모델은 기업의 스스로 환경적, 사회적 실적에 대한 모니터링, 평가를 실시하며 그 결과를 공표하는 단계라고 할 수 있다. 혁신모델 단계에서는 기업 스스로가 CSR 관련 역량을 구축해야 하는 과제를 가지고 있다. 통합(integrated) 모델은 기업의 실적을 이른바 '기업시민정신(Corporate Citizenship)'4)에 입각하여 지표를 설정하고 해당 지표의 성취정도를 모니터링, 평가하는 단계의 모델이다. 이 단계는 일관성 있는 모니터링과 평가가 중요 요소라 할 수 있다. 가장 높은 단계인 전환모델은 기업의 활동이 사회적 지지를 받는 단계이며, CSR의 주체가 다양화, 상호 결합되는 단계라고도 할 수 있다. 예를 들어, 기업, 지역사회 그룹 그리고 $\mathrm{NGO}$ 가 문제의식을 공유하며, 기업 활동과 지역 공동체 발전이 자연스럽게 조화를 이루는 단계라고 할 수 있다.

3) 출처: Corporate Citizenship Center, http://www.bcccc.net/index.cfm?pageld=2009

4) 다보스 포럼(Davos Forum)의 창시자인 클라우스 슈왑(Klaus Schwab) 교수가 2008년 저널 'Foreign Affairs journal'을 통해 언급한 개념으로, 기업의 활동영역이 사회 직 - 간접 투자, CSR 등을 뛰어넘어 '국제적 공간' 으로 확대되었다는 것을 전제로 한다. 하지만 다국적 기업, 글로벌 기업 등의 명칭은 단순히 자국 외에서 활 발히 활동하는 기업을 의미하는 것이 아니며, 기업의 시민정신이란 기업이 세계 도처에서 발생하는 거시적 단계의 이슈에서부터 접근하여 미시적 단계의 사회 문제까지 연계하며 지속 가능한 국제 경쟁 질서를 바로 잡으려는 문제의식에 그 바탕을 둔다. 


\section{2 기업의 글로벌 CSR 현황}

2000년대 중반 이후 UN과 NGO 등은 UN은 기업의 '지속가능발전(sustainable development)'5) 이란 개념을 발전시키면서 기업의 사회적 책임 관련 규범을 설정해 왔다. 또한 CSR 관련 표준지침을 설정하면서 기업의 경영적, 사회적 책임에 대한 국제적 규범을 제시하기 시작했다. 대표적인 기준으로 Global Compact 10대 원칙, Global Reporting Initiative, ISO26000 등을 꼽을 수 있다. 한편, 세계경제포럼(WEF)은 기업의 글로벌 시민의식은 기업의 이익을 보다 보장해준다고 강조하며, 이를 촉구하고 있다. 즉, 기업의 번영과 지속적 성장은 글로벌 정치, 경제, 생태 및 사회적 환경에 의존한다는 점을 주목하며 글로벌 기업 경영활동의 필수 조건으로 제안하고 있다. 1995년 160여 개 다국적 기업의 연합체로 출범한 세계기업협의회(World Business Council for Sustainable Development)도 기업이익, 환경 지속성, 사회적 책임이라는 triple-bottom-line의 지속적인 실적 모니터링과 평가를 통한 지속가능한 발전 달성을 지향하고 있다. 이번 장에서는 이러한 배경 하에 기업의 지속가능한 성장과 사회공헌활동을 중심으로 기업의 글로벌 CSR 논의와 현황을 살펴본다.

미국과 유럽의 Global CSR에 대한 인식과 정책 동향을 간단히 보면, 미국은 전형적으로 주주의 이익에 부합하는 CSR 전략을 추구하는 경향을 보이다가 2000년대 들어 지역사회에 대한 사회적 책임을 강조하고 있다. 90년대 중반부터 최상의 국제비즈니스관행 프로그램(Best Global Business Practices Program) 설정을 통해 국제 거래 시 기업의 사회적 책임과 윤리 수준의 향상을 꾀하고 있으며, 특히 뇌물, 탈세, 공정거래법 위반 등의 윤리적 규준을 강화하고 있다. 이러한 규준은 글로벌 CSR의 단계와 수준을 끌어올리는 기반으로 작용하고 있다. 전통적으로 기업의 자발적 $\mathrm{CSR}$ 을 강조해온 유럽에서도 90년대 중반 사회적 책임 관련 법규를 정비하고 1996년 유럽연합의 지원 하에 기업윤리추진 단체인 'CSR 유럽'을 출범시켰다. 당시 이 조직에는 로열더치셀, 다농, 폭스바겐, 존슨\&존슨, IBM, 나이키, 유니레버 등 59 개 업체가 연 5 만유로의 회비를 내고 자발적으로 참여 했다. 2000년 리스본에서 열린 $\mathrm{EU}$ 정상회의에서 유럽연합은 유럽의 지속가능한 경제성장과 경쟁력 있는 지식경제체로서의 유럽 구축이라는 목표를 달성하기 위한 방안으로 CSR을 지원할 것을 표방하였다. 2006년 3월에 개최된 유럽위원회의 브뤼셀 위원회에서는 유럽연합의 '성장과 일자리를 위한 파트너 십'을 핵심의제로 상정하고 이를 수행하기 위해 'CSR 유럽동맹(European Alliance for CSR)'을 결성하기도 했다(홍성헌, 이수형, 2009). 이 조직은 유럽을 사회적 책임의 모범사례로 만드는데 일조했으며, 특히 CSR을 '성장과 일자리 창출'에 기여하는 전략적 도구임을 규정하고 이를 활성화하는데 기여했다고 평가받고 있다.

해외 기업의 글로벌 CSR 동향을 보면, CSR 전략과 경영전략이 부합할 때, 특히 CSR활동이 기업의 핵심사업 분야와 높은 연관성을 가질 때 높은 효과성을 가지는 것으로 나타남을 알 수 있다. 예를 들어 도요타는 90년대 후반부터 전 세계적으로 환경보호관련 기업의 CSR을 강조해 왔으며,

5) 지속가능발전 개념은 자연과 천연자원보전을 위한 국제연합(IUCN)이 UN 환경프로그램, 세계야생기금(WWF) 의 도움을 받아 1980년에 발표하고 UN총회가 채택한 '세계 환경보전 전략'에서 시작되었다. 이후 1987년 ‘환경과 개발에 관한 세계위원회 보고서-인류 공통의 미래' 보고서는 지속 가능발전을 '미래세대의 욕구 충 족 능력을 희생시키지 않으면서 현 세대의 욕구를 충족시키는 발전'으로 규정했다. 
이는 환경경영을 통한 친환경자동차 시장의 선도라는 경영전략과 부합했다. 이러한 전략은 1997 년 친환경 하이브리드 자동차 '프리우스' 출시를 가능하게 했으며, 이후 하이브리드 기술 선점을 통한 세계시장에서의 안정적 판매고를 이룩하면서 자동차 산업에 엄격히 적용되는 국제 환경규제에도 적극적(효과적)으로 대응하는 결과를 만들어 냈다. 또한 마이크로 소프트사의 경우 소외계층지원을 기업의 사회적 책임 영역으로 설정하면서 이를 경영전략에 반영, 저소득층에 대한 컴퓨터 이용 지원과 개도국의 정보격차 해소를 위한 컴퓨터 기술향상 도모 등을 통해 전 세계적으로 잠재적 시장 확보에 성공해 오고 있다고 평가 받고 있다(홍성헌, 2010, 홍성헌 · 이수형, 2009).

현재 기업의 글로벌 CSR 현황을 파악할 수 있는 자료 중 하나는 UN 산하 기구인 Global Compact 의 Global Corporate Sustainability Report 이다. Global Compact에 가입한 140개국의 8,000 여 기업 대상으로 '지속가능경영현황'조사를 실시했으며, 이중 113 개국 1,712 개 기업이 설문에 응했다. 이를 바탕으로 2013 년 9월 발간된 보고서는 현재 기업의 Global CSR 관련 현황과 동향을 파악하는데 도움을 준다. 왜냐하면 Global Compact가 설정한 인권, 노동, 환경, 반부패에 관한 10 대 원칙(과 지속가능경영 성과는 기업의 Global CSR 추진능력과 밀접한 관계가 있기 때문이다. 즉, 기업의 재무적 성과 뿐 아니라 환경, 사회 부문의 성과는 기업의 경쟁력과 지속가능한 성장에 매우 큰 영향을 미친다고 판단된다.

설문 결과를 요약하면, 우선 기업의 선의(good intention)가 의미 있는 행동(significant actions) 으로 '막 옮겨지고 있는' 단계이다. 하지만 지속가능경영의 정책 입안과 실제 실행사이에는 여전히 큰 격차가 존재하고 있다. 조사 결과에 따르면 응답 기업의 $65 \%$ 가 $\mathrm{CEO}$ 선에서 지속가능성 관련 정책과 전략이 수립되지만 관리자 급에서 실제 이행률은 $35 \%$ 에 불과하고 있음을 알 수 있다. 인권, 노동, 환경, 반부패 관련 UN Global Compact 10대 원칙의 실행력을 높이기 위한 방안도 모색되고 있는데, 인권부문에서는 고충처리제도, 노동부문에서는 직원성과평가 및 교육, 환경부문에서는 물발자국 (water footprint) $)^{7}$ 및 제품 주기 평가, 반부패 부문에서는 직원 법규위반에 대한 적절한 제제 초치 마련 등이 대안으로 제시되고 있다. 또한 현재 기업과 소비자, 기업과 투자자 간의 커뮤니케이션이 제대로 이루어지고 있지 못하며 지속가능한 발전을 위해서는 적극적인 커뮤니케이션 방안을 모색할 필요성이 대두되고 있다.

둘째, 대기업이 여전히 지속가능경영을 선도하고 있는 것으로 나타났다. 이는 지속가능경영 성과에 기업의 규모가 여전히 중요한 요인으로 작용하고 있음을 의미한다. 대기업과 소기업의 해당성과

6) 10 대 원칙은 다음과 같다. 인권 (Human Rights) 부문, 원칙 1: 기업은 국제적으로 선언된 인권 보호를 지지하 고 존중해야 한다. 원칙 2: 기업은 인권 침해에 연루되지 않도록 적극 노력한다. 노동규준(Labour Standards) 부문, 원칙 3: 기업은 결사의 자유와 단체교섭권의 실질적인 인정을 지지하고, 원칙 4: 모든 형태의 강제노 동을 배제하며, 원칙 5: 아동노동을 효율적으로 철폐하고, 원칙 6: 고용 및 업무에서 차별을 철폐한다. 환경 (Environment) 부문, 원칙 7: 기업은 환경문제에 대한 예방적 접근을 지지하고, 원칙 8: 환경적 책임을 증진 하는 조치를 수행하며, 원칙 9: 환경 친화적 기술의 개발과 확산을 촉진한다. 반부패(Anti-Corruption) 부문, 원칙 10: 기업은 부당취득 및 뇌물 등을 포함하는 모든 형태의 부패에 반대한다.

7) 기업이 생산한, 개인이나 공동체가 사용하는 재화나 용역에 들어간 담수의 총량을 계산한 것으로 네덜란드 트벤테 대학의 아르옌 훅스트라 교수가 고안했다. 즉, 더 많은 물건이 생산되고 사용되고 새것으로 교체될수 록 더 많은 물이 사용된다는 논리로, 물에 관한 환경 영향 수치를 나타낸다. 
차이는 모든 부문에서 나타나고 있는데, 실제로 인권관련 고충처리 장치를 갖추고 있는 기업 비율을 보면, 대기업의 경우 $58 \%$ 에 달했으나 소기업은 $23 \%$ 에 그치고 있다. 그 이유로는 소기업의 재원 부족과 관련 노하우 부족이 꼽히고 있다. 하지만 이러한 격차는 줄어드는 추세에 있으며, 특히 2012 년 이후 중소기업은 인권 관련 규정, 환경 목표 설정, 부패 무관용의 원칙과 측정 지표를 마련하는 등 변화를 보이고 있음이 보고되었다.

셋째, 기업의 하청 구조(Supply Chains)는 성과향상에 걸림돌이 되고 있다. 즉, 모 기업은 하청기업에게도 동일하게 지속가능경영 전략과 그 성과를 요구하지만 하청 기업은 이를 준수할 여지가 없거나 그 노력을 하지 않고 있었다. 설문 결과를 보면, 응답 기업의 $83 \%$ 가 하청기업에게 글로벌 컴팩트 원리(Global Compact Principles) 수행을 요구하고 있지만 $18 \%$ 만이 이를 검토, 목표 점검을 하고 있으며, $9 \%$ 만이 구체적으로 개선하는 단계에 들어섰다. 긍정적인 변화는 대기업이 중소 하청기업에게 다양한 동기부여와 지원방안을 통해 해당 원리를 준수하도록 유도, 요구하기 시작했다는 점이다.

마지막으로 보다 긍정적인 점은 기업들이 교육, 빈곤퇴치, 기후변화, 성장 및 고용률과 같은 현재 보다 시급하고 중요한 이슈를 기업 경영 전략에 반영하고 있다는 점이다. 실제로 UN Global Compact 에 서명한 $70 \%$ 의 기업들이 UN의 목표와 중요 이슈의 이행을 위해 노력하며, 이를 비즈니스의 핵심 원리로 활용하려는 다양한 시도를 하고 있다고 밝히고 있다. 보고서는 실제로 기업들이 개도국 빈곤지역에서의 의료서비스, 정수 및 위생시설, 통신기술, 금융서비스와 같은 혁신을 소개, 전파하고 있다고 기록하고 있다.

국내 기업의 CSR 현황을 판단할 수 있는 자료는 매우 제한적이며, 전경련의 사회공헌 백서 (Corporate Community Relations White Book)는 이를 판단할 수 있는 중요 자료 이다. 백서는 국내 회원 기업들의 사회공헌에 대한 조사, 분석을 통해 기업 사회공헌활동의 실상을 이해하고 향후 바람직한 사회공헌활동 방향을 모색하는 것을 목적으로 하고 있다.

2013년 발간된 백서는 2012년 해당 기업의 사회공헌 규모, 임직원 사회봉사 실적 및 제도, 사회공헌 추진을 위한 사내제도, 기업 사회공헌 인식조사 등을 내용으로 하고 있다. 설문조사는 설문지와 팩스, 이메일, 전화조사를 통해 이루어 졌으며, 대상은 매출액 상위 500 대 기업 및 전경련 주요 회원사 등 600 개 기업이었으며 이 중 225 개 기업이 응답하였다. 이를 통해 백서가 밝히는 국내 기업의 CSR 현황은 다음과 같다.

먼저 사회공헌비용 총 지출 규모를 보면, 응답 기업 225 개사가 2012 년 한 해 동안 지출한 사회공헌 총 비용은 3조 2,494억 9000만원이었다. 이는 2011년 대비 5.2\% 증가한 수치로, 특히 2012년 기업 경영실적이 좋지 않았음에도 불구하고 사회공헌이 양적으로는 증가했다는 점은 그만큼 CSR에 대한 기업의 노력이 증대하고 있다는 의미로 해석될 수 있다. 평균 지출액 규모도 유사한 패턴을 보이고 있다. 
〈표 1〉 연도별 기업 사회공헌 지출규모 및 증가율 추이

(단위: 백만원, \%)

\begin{tabular}{c|r|r|r|r|r|r}
\hline & $\begin{array}{c}2007 \\
\text { (208개사) }\end{array}$ & $\begin{array}{c}2008 \\
(209 \text { 개사) }\end{array}$ & $\begin{array}{c}\text { 2009 } \\
\text { (220개사) }\end{array}$ & $\begin{array}{c}\text { 2010 } \\
\text { (220개사) }\end{array}$ & $\begin{array}{c}2011 \\
\text { (225개사) }\end{array}$ & $\begin{array}{c}2012 \\
\text { (225개사) }\end{array}$ \\
\hline 총 지출액 규모 & $1,955,642$ & $2,160,141$ & $2,651,756$ & $2,873,505$ & $3,088,382$ & $3,249,490$ \\
\hline 전년도 대비 증가율 & $8.4 \%$ & $10.5 \%$ & $22.8 \%$ & $8.4 \%$ & $7.5 \%$ & $5.2 \%$ \\
\hline 평균 지출액 규모 & 9,402 & 10,336 & 12,053 & 13,061 & 13,726 & 14,442 \\
\hline 전년도 대비 증가율 & $4.7 \%$ & $9.9 \%$ & $16.6 \%$ & $8.4 \%$ & $5.1 \%$ & $5.2 \%$ \\
\hline
\end{tabular}

출처: 전경련, 2013: 52

한편, 2012년 매출액 및 이익대비 사회공헌활동 지출 비율은 $0.22 \%$ 로 전년도와 유사한 수준으로 나타났다. 또한 매출액 대비 사회공헌 지출비율 분포를 보면, $0.05 \%$ 이상 $0.1 \%$ 미만을 사회공헌에 지출하는 비율이 $44.4 \%$ 로 가장 많았으며, $1 \%$ 이상 지출하는 기업은 31 개 기업, $13.8 \%$ 에 머물렀다. 2002년부터 2012년까지 매출액 대비 사회공헌 지출 비율은 평균 $0.2 \%$ 로 나타났다. 이러한 비율은 외국기업의 그것보다 낮지 않은 수치이다. 예를 들어 2012년 기준 세전이익 대비 사회공헌 비중은 우리나라가 $3.58 \%$ 로 일본의 $1.71 \%$ 보다 높게 나타났다.

운영방식별 지출 현황을 보면, 기부 형태가 $62.5 \%$ 로 가장 많고, 직접사업의 형태는 $37.5 \%$ 로 조사되었다. 기업의 사회공헌 지출구성 중 기부 형태의 비중이 높은 것은 다양하게 해석될 수 있지만, 우선 기업이 $\mathrm{NGO}$ 등 외부조직과 기부를 통한 협업의 경우가 많다고 해석될 수 있다. 이는 현 상황에서 한국 기업이 사회공헌관련 자체 노하우나 전문성을 가지고 있지 못함을 의미하기도 한다. 그런데 파트너십의 성격을 보면, 이전에 단순기부, $\mathrm{NGO}, \mathrm{NPO}$ 지원 활동에 머무르던 것이 기업스스로가 사회 공헌 활동 영역을 개척하고 관련 노하우를 축적하는 것으로 전환되고 있다. 이러한 전환과 함께 직접 사업의 비중 또한 증가하고 있는 것으로 나타났다. 2000 년 이전 직접사업의 비중은 $10 \%$ 미만이었으나, 2000년 이후 매년 30\%대 수준을 유지하는 등 기업이 독자적으로 사회공헌의 내용과 형식을 주관하려는 추세이다. 또한 이는 CSR을 기업 경영철학에 반영하려는 의지의 표현으로 해석될 수 있다.

〈표 2〉기업의 사회공헌 형식 변화: 기부와 직접 지출 현황

(단위: \%)

\begin{tabular}{c|r|r|r|r}
\hline & \multicolumn{2}{|c|}{1998} & 2000 & \multicolumn{2}{c|}{2010} & 2012 \\
\hline 기부 & 95.6 & 95.0 & 62.0 & 62.5 \\
\hline 직접운영 & 4.4 & 5.0 & 38.0 & 37.5 \\
\hline
\end{tabular}

* 해당항목 응답기업 기준(1998년 147개사, 2000년 193개사, 2010년 187개사, 2012년 188개사)

출처: 전경련, 2-13: 57 
분야별 지출현황을 보면, 사회복지에 대한 지출이 $31.7 \%$ 로 가장 높고, 교육· 학교 · 학술연구 부문이 $16.1 \%$, 문화예술 및 체육 부문이 $11.1 \%$ 로 나타났다. 그런데 조사 결과 중 특징적인 점은, 기업들이 전통적으로 관심을 가져온 사회복지, 교육, 문화예술 부문 외에 '기타 분야'가 $25.7 \%$ 로 조사된 점이다. 이는 기업의 사회공헌 관심분야가 기존 영역으로 분류되기 어려운 취약계층 일자리 창출, 전통시장 지원, 청년 창업 등 다양한 부문으로 확대되었음을 의미하며, 단순 취약계층 현금지원이 아닌 사회복지 · 문화예술적인 요소가 복합적으로 접목되는 등 다변화된 추세를 반영한 것으로 보인다.

사회공헌의 형태별 지출 비율을 보면, 우선 기부금의 경우 사회복지 분야가 $45.7 \%$ 로 가장 높은 비중을 차지하고 있다. 이는 취약계층을 지원하는 사회복지분야가 아직까지는 우리사회에서 가장 필요로 하는 기업의 사회공헌활동 분야로 인식되기 때문으로 분석된다. 한편 직접사업 프로그램의 분야별 비중을 보면 ‘의료보건' 분야가 2012년에는 30.9\%로 가장 높은 것으로 나타났는데, 이는 2012년 대규모 의료 센터건립 사업 등에서 기인한다. 그 외에는 교육·학교 · 학술연구 부문이 $18.2 \%$ 로 가장 높았다. 주목되는 것은 분야에 따른 기업의 사회공헌활동 접근방식이 상이하다는 점이다. 즉, 사회복지 분야는 $\mathrm{NPO}$ 등 외부단체와의 파트너십을 선호하며, 교육·학교·학술연구 분야는 기업의 사업 분야의 특성에 따라 직접 사업의 선호도가 높다는 사실이다.

기업의 기부 형태를 보면, 2012년 기준 현금기부가 $96.4 \%$ 로 대부분을 차지했음을 알 수 있으며, 출처는 자사출연단체에 대한 기부가 $40 \%$ 를 상회하였다. NPO에 대한 지원은 $35.6 \%$ 로, 2011년 $28.6 \%$ 에 비해 상승했다. 기부의 형태가 현금 기부로 이루어진다는 점은, 기업의 사업 노하우를 기부에 활용하는 방법, 프로보노(probono) $)^{8)}$ 등 새로운 기부형태를 모색할 필요성을 느끼게 한다.

한편, 응답 기업은 대부분 사회공헌 추진을 위한 사내 제도를 가지고 있는 것으로 조사되었으며, 이는 사회공헌의 분위기가 어느 정도 사내에 정착, 당양한 형태로 제도화 되고 있음을 의미한다. 그 예시를 보면, 지역 사회활동 촉진 운동에서부터 내부 모니터링 시스템 구축 등 다양한 형태로 이루어지고 있음을 알 수 있다. 하지만 기업 경영전략의 일부분으로서의 체계적이며 전략적 CSR 형태는 아직 보이지 않고 있다.

〈표 3〉 사회공헌활동 추진 사내체제 예시

\begin{tabular}{l|l}
\hline & \multicolumn{1}{c}{ 촉진제도 예시 } \\
\hline & - 지역 소규모 식당이용 캠페인, 사업장 소재 지역 취약계층 지원 \\
지역사회활동 촉진운동 & - 환경보호, 1사 1촌 농어촌 자매마을, 명절 직거래 장터 개설 \\
& - 정기적 전사차원 봉사활동 캠페인 \\
& 단위조직별 CSR FT(facilitator)를 중심으로 지역기반 자원봉사 활동 및 조직별 \\
& 업무연계 사회공헌활동 발굴/시행 독려
\end{tabular}

8) 프로보노(probono)는 미국 변호사들의 무료 법률상담 활동에서 나온 개념으로, 전문 인력의 재능과 기술이 사회공헌에 활용됨을 의미한다. 


\begin{tabular}{|c|c|}
\hline & 촉진제도 예시 \\
\hline $\begin{array}{l}\text { 경영방침에 사회공헌 } \\
\text { 명문화 }\end{array}$ & $\begin{array}{l}\text { - 경영방침 내에 지역밀착 경영, 공유가치, 환경가치경영, 그룹 경영이념, } \\
\text { 인류 건강, 사회적 책임경영 등 }\end{array}$ \\
\hline 내부모니터링 시스템 & $\begin{array}{l}\text { - 자원봉사활동과 임직원 인식조사, 사회공헌 } \mathrm{KPI}, \text { 사회공헌 규정 제작 } \\
\text { - 자원봉사활동 내용 및 후기 } \mathrm{DB} \text { 화 } \\
\quad \text { (부서별, 개인별 관리, 건의사항 반영, 제안사항 접수) } \\
\text { - 사회공헌활동 인지도 조사, 봉사단 코디네이터 및 결연기관 의견조사 } \\
\text { - 자체 사회공헌프로그램 평가지표 등 }\end{array}$ \\
\hline $\begin{array}{l}\text { 전담자의 전문성 제고 } \\
\text { 프로그램 }\end{array}$ & - 사회공헌 전략 워크숍, 국내외 컨퍼런스 참가, 자원봉사단 코디네이터 워크숍 \\
\hline $\begin{array}{l}\text { 사회공헌 추진관련 } \\
\text { 사내위원회 등 추진 }\end{array}$ & $\begin{array}{l}\text { - 사회공헌위원회, 기부위원회, 공익사업 운영협의회, 봉사단 운영위원회 } \\
\text { - 지속가능경영위원회, 사회공헌추진위원회, CSR Committee, 사회공헌 평가위원회 } \\
\text { - 사회공헌실무협의체, } 1 \% \text { 나눔 협의회 사회책임위원회 }\end{array}$ \\
\hline 기타 & $\begin{array}{l}\text { - 글로벌 해외봉사활동, 장기휴가 봉사활동, 사회공헌활동 백서 발간 } \\
\text { - 자원봉사환동 가이드 책자 발간, 인트라넷 내 나눔 활동 메뉴개발 오픈 } \\
\text { - 사회공헌포털사이트 운영, 자원봉사 교육학점제도, 프로보노 도입 } \\
\text { - USR(Union Social Responsibility) }\end{array}$ \\
\hline
\end{tabular}

출처: 전경련, 2013: 67

기업의 파트너십 형성관련 선정 분야와 그 이유 등을 살펴보는 것은 미래의 기업 CSR 발전 전략형성과도 큰 연관성을 가진다. 응답 기업은 기업의 파트너십 선정기준 중, '사회적 필요성 및 효과성'(41\%), '기업 사회공헌 철학과의 적합성'(40\%)을 가장 중요한 근거로 꼽고 있다. 백서는 이러한 자료를 바탕으로 우리 기업들이 사회공헌활동과 기업특성과의 합치성에 대한 욕구가 커지고 있다는 점을 지적하고 있다. 실제로 이러한 점은 글로벌 CSR 전략을 발전시키고 있는 외국 기업의 경우 중요한 원칙으로 고려되는 것을 볼 때, 향후 중요하게 주목되어야할 부문이다. 실제로 사회공헌 트랜드를 보면 기업 업종 연계형 사회공헌프로그램 개발에 대한 추진 비율이 84\%(복수응답)로 가장 높게 나타났다.

또한 기업 사회공헌 활동에 대한 내부 평가시스템도 가동시키고 있는데, 크게 사회공헌관련 비용, 임직원 봉사활동 실적(참여율, 시간), 수혜자 수 등 정량적 평가와 이해관계자 만족도 조사, 지역사회 변화 정도 등 정성적 평가로 나뉘고 있다. 사회공헌 관련 공통지표 마련의 필요성에 대해서는 다수의 기업이 '필요하다(72\%)'고 응답했다.

마지막으로 기업 사회공헌의 저해 요인 분석(1,2,3 순위 중복 응답)에서는, 내부 저해요인으로 담당인력, 전담 부서 부재를 가장 큰 원인으로 꼽았으며(26.8\%), 그 외 예산부족, 사회공헌에 대한 기업 내부 이해 부족 등을 들었다. 외부 저해요인으로는 정부의 지원 부족(26.4\%)과 외부의 왜곡된 시선(26.4\%)를 가장 큰 원인으로 들었으며, 그 외 외부의 압력과 요구(24.0\%), 사회적 인정부족 (17.6\%) 등을 꼽았다. 


\section{Global CSR 과 CSR-PPP}

이번 장에서는 글로벌 CSR의 다양한 파트너십 형성과 성과를 CSR-PPP(Public Private Partnership) 사업 사례를 중심으로 소개해보고자 한다. CSR-PPP 개념9)은 원조의 효과성을 높이는 기제로서의 다양한 파트너십을 의미하며 글로벌 CSR이 발전함에 따라 적극적으로 고민되어져야 하는 사업형태라 할 수 있다. 즉, CSR-PPP 개념은 개발협력과정에서의 PPP는 'CSR'과 '개발' 이라는 가치가 상호 조화를 이루어야 한다는 전제에서 출발하고 있다.

글로벌 CSR을 바탕으로 한 주요국의 ODA분야 PPP 사례들 중 가장 주목 받는 것은 미국의 '글로벌개발연대 GDA(Global Development Alliance)' 사업이다. 이는 정부, 기업, NGO 및 국제기구 등 최소 3 자 이상이 계약을 체결하여 각기 재원과 위험부담을 공유하여 개발, 지원사업 진행하는 방식으로, 계약 당사자에 최소한 3개 주체(USAID, 민간기업, USAID 외 정부기관, 지방정부, 국제기구 또는 민간단체)가 포함된다. 재원 부담을 보면, USAID는 사업 재원의 $1 / 3$ 에서 $1 / 2$ 를, 민간은 $1 / 4$ 이상 분담하며, 특징적인 것은 민간부문의 기여는 현물지원, 기술지원, 지적재산 지원 등도 가능하다는 점이다. GDA는 주로 민간기업 또는 $\mathrm{NGO}$ 의 제안으로 착수되는데, 파트너 간의 공동 목표를 설정하고, 각 파트너의 비교우위에 따라 역할을 분담한다.

대표적인 GDA 사례로 언급되는 것은 르완다 스타벅스 커피 생산 사업이다. 르완다 커피농장 조성 및 농작구조 향상을 목표로 하는 이 사업은, 2006년 민간 기업이 USAID와 협력, 르완다 커피 농장지원을 지원하는 형태로 시작되었다. 즉, 사업 파트너는 USAID, 스타벅스, 르완다 정부 그리고 Chemonics라는 개발컨설팅기업이다. 사업 내용을 보면, 전문가 컨설팅을 통해 고품질의 커피를 더 적정한 값을 받고 팔수 있도록 지원, 농장장비 지원, 농부과정 지원(“cupping and tasting”) 교육, 커피 세탁공장(“Coffee washing station”) 설립 등이며, 여기에 협동조합 설립 지원 요소가 포함되어 있다. 해당 사업은 르완다 내 4 만개 이상의 일자리 창출이라는 가시적 성과를 나타냈다고 보고되고 있다. 그 외 커피 세탁공장의 설립 등 직접적인 민간기업 활성화를 통한 지속적 성장의 근거가 마련된 점, 수익금으로 지역사회 교육사업, 주거환경 개선사업을 지원한 점이 성과로 꼽히고 있다.

Cisco사의 Networking Academy Alliance 참여도 GDA의 성공적 사례로 꼽힌다. 개도국 정보통신분야 시장 개척을 위한 잠재 시장 개발을 목표로 하고 있는 해당 사업은, 애초 Cisco사가 제품을 활용할 수 있는 소비자 부족으로 매출이 정체되는 위기를 맞이하면서 이를 극복하고자 하는데서 출발했다. 1997년 미국 내 7개주에서 Cisco Networking Academy Program 운영하기 시작했으며, 2000 년 이를 24 개 최빈 개도국을 대상으로 확대하였다. 이 사업은 다양한 주체들이 참여했으며, Cisco는 재정(전 세계 아카데미에 1.5억불 투자), 교육 프로그램, 기자재, 기술지원을, USAID는 재정(1999년부터 5백만불 지원), 여성 교육생을 위한 장학금, 전문 인력 지원, 그리고

9) 통상 PPP는 사업 방식을 의미하며 CSR은 가치적인 측면에서 이해된다. 또한 PPP는 계약을 기반으로 한 공 식성을, 이에 비해 CSR은 비공식적인 성격을 가지며, PPP가 보다 넓은 사업 범위를 갖는 한편 CSR-PPP라 함은 그 성격과 범위가 한정될 수 있다. 
$\mathrm{UNDP}$ 는 재정 지원과 함께 기술지원팀을 지원했다. 그 외 JICA는 전문 인력 자원봉사 프로그램을 통한 기술 지원을 했으며, UNV 및 Peace Corps 등 자원봉사단체가 결합되었다. 해당 사업은 다수의 주체들이 각각 강점을 가지고 있는 분야의 노하우를 통해 그 역할을 적정하게 분담, 참여하고 있는 사례이다. 사업의 가장 큰 가시적 성과로는, 우선 41개국에 200개 Cisco Academy가 건립되고 5천 8 백명 이상이 해당 아카데미 수료했다는 것이다.

미국 정유회사인 셰브런(Chevron)의 앙골라 지역 개발협력사업도 글로벌 CSR-PPP 의 모범적 사례로 언급되고 있다. 해당 사업은 27 년간의 내전으로 황폐화된 앙골라 내 지역 사업 개발, 농업 진흥, 이산민 정착 지원 등을 목표로 하고 있으며, 1930년대부터 앙골라에 진출해 있던 셰브런이 2002년 USAID에 1천만 불을 기여하고, USAID는 Africare, CARE, Save the Children, World Vision 등 사업 수행 경험과 전문성을 가진 NGO들과 함께 개발 사업을 수행한 사례이다. 재원은 셰브런 외 USAID가 1천만 불을 분담했다. 사업성과로는, 내전 등으로 발생한 30여만 명의 이산민을 정착, 빈곤층의 식량안보 $45 \%$ 개선, 소액금융기관인 Novo Banco 설립, 800 명에게 평균 5 천불의 소액 대출(상환율 $98 \%$ ) 실적 등이 보고되었다.

미국의 GDA 모델 외, 독일의 'PPP 특별기금', 캐나다의 'ICP(Industrial Cooperation Program)', 영국의 '도전기금(Challenge Fund)', 스웨덴의 'Tetra Pak Value Chain Model', 덴마크의 'B2B(Business to Business)' 등도 글로벌 CSR에 바탕을 둔 다양한 PPP 사업 지원 모델로 소개되고 있으며, 이들 사업의 대표적인 사업성과로는 '개도국 내 민간기업 활성화와 이로 인한 대규모 고용창출'이 꼽히고 있다.

\section{5. 글로벌 CSR과 CSV}

CSV(Creating Shared Value)는 하버드 비즈니스 스쿨의 마이클 포터와 프리스탠더드그룹 (FSG)의 공동창업자 마크 R. 크레이머가 2006년 1월에 하버드 비즈니스 리뷰에 발표한 “전략과 사회: 경쟁 우위와 CSR 간의 연결(Strategy and Society: The Link between Competitive Advantage and Corporate Social Responsibility)"에서 처음 등장한 개념이며, 2011년 1월에 발표한 “공유가치를 창출하라: 자본주의를 재창조하는 방법과 혁신 및 성장의 흐름을 창출하는 방법 (Creating Shared Value: How to reinvent capitalism-unleash a wave of innovation and growth)"에서 본격적으로 확장된 개념이다.

흔히 CSV는 CSR과 비교되면서 개념 규정이 되는데, 엄밀히 말해 CSV는 특정 CSR 단계에서 추구되는 가치 혹은 지향점이라고 볼 수 있다. 그간 언급되어온 논의를 중심으로 양자 간 차이를 정리해 보면 다음과 같다. 


\section{〈표 4〉CSR과 CSV의 차이점}

\begin{tabular}{c|c|c}
\hline & CSR & CSV \\
\hline 가치 & 선행(Doing Good) & 투입비용 대비 높은 사회경제적 가치 \\
\hline 활동 & 시민의식을 전제로 한 자선 활동 & 기업과 공동체 모두를 위한 가치창출 \\
\hline 인식 & 이윤극대화와는 무관한 개념 & 이윤극대화를 위한 필수요소 \\
\hline 예산 & $\begin{array}{c}\text { 기업의 CSR 예산을 별도로 설정 } \\
\text { (통상 매출액 대비 1\%미만) }\end{array}$ & 기업 전체 예산에 반영 \\
\hline 담당 부서 & 별도 부서 구성 & 모든 부서에 반영 \\
\hline 지속성 & $\begin{array}{r}\text { 기업 손익상황과 연계 } \\
\text { (경제 위기 시 사업 수행 중단) }\end{array}$ & 단기적 손익상황과 무관하게 진행 \\
\hline 소통방향 & 기업이 사회에 대한 일방적 소통 & 기업과 사회(소비자) 간 쌍방 소통 \\
\hline 가치평가 & 사회 가치에 대한 평가 시스템 미비 & 사회 가치에 대한 사전적 평가 \\
\hline 가치평가연계 & 기업의 가치와 사회 가치 연계 미흡
\end{tabular}

출처: 마이클 포터, 2009, 조동성 2009, 저자 재구성

CSR이 기업이 이미 만들어 낸 이익의 일부를 선행(Doing Good)에 쓰는 방식이라면, CSV는 처음부터 투입 대비 높은 경제적, 사회적 가치의 창출을 지향하고 있는 방법이라 할 수 있다. 또한 기업들은 CSR을 ‘비용’으로 인식하고 있으며 해당 예산은 한정적이기에 활동 또한 제한적이다. 반면 $\mathrm{CSV}$ 는 사회, 경제적 가치의 증가가 기업의 경쟁력 향상으로 이어진다고 인식하고 있다. 따라서 기업 전략은 이러한 문제의식으로 재창조 되어야 하며, 이를 위해 특정 부서가 아닌 기업 전체 조직이 관련되고 전체 예산에 해당 비용이 투입되어야 한다. 한마디로 CSV는 사회에 공헌하는 활동을 통해서 매출과 이익을 증대시키고, 사회 문제 해결이 기업의 경제적인 가치창출활동과 일체화 (integrated)되어 있다.

조직 내 담당 부서 형성의 시각에서 보면, CSR이 별도의 부서나 기업 PR 활동의 일환으로 이루어지는 것에 비해서, CSV는 전사적으로 이루어진다고 볼 수 있다. 따라서 CSV를 위한 별도의 조직이 구성되지 않으며, 이러한 맥락에서 CSV는 기업 고유의 비즈니스와 관련이 없는 분야의 사회공헌 프로그램은 추진하지 않는다.

또한 $\mathrm{CSV}$ 가 기존의 기업 사회 공헌 방식인 $\mathrm{CSR}$ 와 가장 큰 차이를 보이는 점 중에 하나는 '비즈니스 연계'다. 예를 들어 CSR는 자선 활동에 초점이 맞춰져 있고, 기업은 CSR를 통해 기업의 평판과 이미지를 높이는 데 주력하며, 높아진 기업 이미지는 기업의 미래에 새로운 프로젝트를 추진하는 데 도움을 준다. 그 결과 기업의 지속 가능성은 더 높아진다는 논리이다. 그러나 기업이 CSR 활동을 시작했다고 하더라도 이윤이 제대로 창출되지 않는다면 CSR은 계속될 수 없다는 구조적 한계를 가지고 있다. 이에 비해 CSV는 프로젝트 수립 단계에서부터 사회적 가치를 고려한다. 즉, 프로젝트 수립 단계에서부터 이윤 창출은 물론 사회적 가치까지 포함되어 있다는 것이다. 한마디로 
$\mathrm{CSR}$ 이 현재의 파이를 재분배하는 것에 관심을 둔다면, 예를 들어 $\mathrm{CSV}$ 는 개도국 농촌의 농법을 개선하고 농부를 위한 지역 협력과 지원 체계를 구축하는 방법을 고민한다는 것이다. 이를 통해 사회 전체적인 파이 자체가 커지는 것이다.

또한, CSV는 CSR보다 기업 친화적이라고 평가된다. ‘책임’보다 ‘공유가치’라는 용어가 경영자의 부담을 경감시킬 수 있고, 사회적 가치 창출을 기업의 가치사슬 안에서 이뤄낼 수 있다는 논리는 기업입장에서 설득력과 공감대를 가진다는 것이다. 즉, 수익 극대화와 사회적 가치 창출이 나누어진 것이 아닌 융합될 수 있는 측면에서도 CSV 전략은 자연스럽게 기업 핵심전략의 하나로 자리 잡을 가능성이 높다. 그렇지만 'CSR도 제대로 정착되지 못한 상황에서 CSV가 가능할까'라는 지적도 있듯이, ' $\mathrm{CSR}$ 전략 형성과 발전이 이루어지지 못했던 기업이 하루아침에 CSV 가치를 추구하고 해당 전략을 수립하는 것이 가능할까'라는 비판적 질문 또한 존재한다. 즉 CSV는 소극적 CSR 혹은 ‘방어적 CSR'에서 '전략적 CSR'로 변화되는 '과정'에서 주목받고 있다고 보는 것이 맞다. 즉, 기업의 '전략적 CSR' 단계에서 CSV를 지향하고 있음이 주목 받는 것이지 CSR의 발전 과정과 무관한 CSV 는 실행될 수 없다는 점을 주지해야 한다. ${ }^{10)}$

최근 한국 기업들 사이에서도 CSV를 경영 혁신의 핵심 방법론으로 채택하는 사례가 크게 늘어나고 있다. 이는 기업이 연계 기업, 산업계 구성원, 취약 계층 등 여러 사회적 구성원과 더불어 건강한 산업 생태계를 조성하고 비즈니스 핵심 경쟁력을 강화함으로써 지속 가능한 성장을 한다는 지향점을 가지고 있다. 결국 기존의 CSR이 '도와주기' 차원이었다면 이제는 CSV를 통해 대기업 · 중소기업 · 소비자 · 지역사회 모두가 '상생하는 모델'을 구축하고자 함이다.

현재 전 세계적으로 CSV의 성공적 사례로서는 미국의 홀푸드 마켓(the Whole Foods Market), 스페인 에울렌 그룹(Grupo Eulen), GE(General Electric)의 '에코메지네이션(Ecomagination), 네슬레 등이 주로 꼽히고 있다. 성공사례들은 마이클 포터 교수에 의해 제시된 공유가치 창출의 세 가지 방법을 중심으로 언급되고 있다. 첫 번째 방법은 상품과 시장에 대한 재해석이며, 기존 기업들이 관심을 갖지 않았던 '저소득층 니즈 충족형' 제품을 생산하는 것으로 '지역 소외계층 일자리 창출형' 사업을 그 예로 들 수 있다. 예를 들어 지역 농산물 유통회사인 홀푸드 마켓은 해당 지역사회의 장애인이나 노인들을 고용하여, 이익을 사회에 따로 기부하지 않고서도 지역사회 이슈를

10) 프리스탠더드그룹(FSG)는 2011년 9월에 발표한 CSV 가이드라인인 "Creating Shared Value: A Howto Guide for the New Corporate (R)evolution"을 통해 기업이 CSV를 실행하기 위한, 비전(Vision), 전략 (Strategy), 실행(Delivery), 성과(Performance) 등 네 가지 핵심 카테고리를 제시하고 있다. 우선, 기업은 CSV 를 추진하기 위해서 명확한 비전을 제시해야 한다. 비전 형성에는 기업 관리자의 리더십이 중요한 역할을 한 다. 전략에 해당하는 단계는 이슈 선정, 목표 설정이다. 주요한 점은 목표가 구체적인 수치와 방향성을 담고 있어야 한다는 점이다. 이를 바탕으로 세부적 사업 계획 수립이 가능하며, 조직 내외부의 책임감을 강화시킬 수 있기 때문이다. 실행에 해당하는 단계에는 자산 활용, 통합 관리, 파트너십의 프레임워크가 작동된다. 어 느 한 부서 역량이나 제한된 자원의 투입이 아닌, 기업 내 현금, 상품 및 서비스, 인력, 사회적 영향력 등의 유 무형의 자산이 CSV 계획 수립에 적극 활용되어야 한다. 성과에 해당하는 단계에서는 사업 전반에 대한 정보 뿐만 아니라 사업의 결과로 인한 사회적 변화가 체계적으로 관리되어야 한다. 그리고 이러한 결과를 통해서 교훈을 습득하고, 습득한 교훈을 다시 시스템에 반영하여 프로젝트를 확대하여 공유 가치를 극대화한다. 마 지막으로 전 과정을 통해 축적한 데이터와 결과를 지속가능보고서 이외의 다양한 수단과 매체를 통해 내부 와 외부의 이해관계자들과 공유해야 한다. 
해결하는 유형이라 할 수 있다. 스페인 최대 인력파견 기업인 에울렌 그룹(Grupo Eulen)사례도 이와 유사하다. 해당 기업은 장애인, 이민자 등 소외계층에게 일자리를 창출해주는 방식으로 사회문제와 기업 이윤을 동시에 달성했다고 평가 받는다. 수행과정에서 제기되었던 이민자, 장애인의 서비스에 대한 소비자의 불만과 우려는 철저한 사전교육으로 해결했으며, 고용된 소외계층에게도 차별 없는 노동조건을 제공함으로써 이들의 회사에 대한 높은 충성도를 끌어내는데도 성공했다.

둘째, 가치사슬의 생산성에 대한 재 정의를 통해서 CSV를 추구할 수 있다. 즉, 기업 특성별로 가치사슬 단계에서 발생하는 사회 - 환경적 영향을 고려하여 각 단계의 생산성과 연계된 사회 환경 목표를 설정해야 한다는 것이다. 해당 방법은 $\mathrm{GE}$ 의 '에코메지네이션(Ecomagination)' 사례가 대표적으로 언급되는데, 기업은 2005년부터 친환경 제품과 서비스로 수익을 올리는 동시에 환경문제 해결에 도움을 주는 전략을 추진하고 있다. $\mathrm{GE}$ 는 에코메지네이션 전략의 목표인 청정기술투자 확대, 환경사업 매출 증대, 온실가스 배출 감축, 에너지효율 향상 등을 구체적인 수치로 제시하고, 전략 수행을 위해 외부전문가로 구성된 자문단을 운영, 목표대비 성과를 매년 연례보고서 등을 통해 투명하게 공개하고 있다.

셋째, 클러스터(Cluster; 산업집적지) 구축을 통한 CSV 추구 방법이다. 이는 기업이 경쟁력을 확보하고 사회와 함께 성장하기 위해서는 지역 공급업체, 인프라, 재능 있는 인력 등이 적절하게 융합된 산업 클러스터를 구축해야한다는 점을 강조하고 있다. 사례로는 커피 클러스터의 대표적 형태인 네슬레의 네스프레소(Nespresso)가 언급된다. 네슬레는 커피 생산 농가를 대상으로 농업기술 교육을 제공하고, 이들이 농업 시설이나 기술 및 기계, 유통 채널, 금융 서비스에 접근할 수 있는 클러스터를 개발, 제공해 왔다. 이를 통해 커피농가는 높고 안정적인 수익증대를, 기업은 우수한 품질의 원두를 안정적으로 공급받아 캡슐 커피 시장을 성공적으로 선점하게 되었다.

\section{6. 결론과 시사점}

이상의 글로벌 $\mathrm{CSR}$ 논의 정리와 기업들의 현황 분석을 통해 다음 몇 가지 결론과 시사점을 도출해 볼 수 있다. 첫째, 개발협력과정에서 Global CSR 프로그램은 국제적 요구와 Global Compact 10 대 원칙, Global Reporting Initiative, ISO26000 등 국제 표준화 규준은 보다 엄격히 준수되어야 하며, 이는 개도국 기업의 입장에서도 진출 국가의 사회, 경제적, 문화적 환경 요인 등에 대한 성공적 적응과 이를 통한 장기적인 관점에서의 이윤창출에도 긍정적 요인으로 작용한다.

둘째, 글로벌 컴팩트(Global Compact)의 Global Corporate Sustainability Report 등에 따르면, 전 세계적으로 글로벌 CSR은 혁신의 단계에 들어서 있으며, 기업의 '선의(good intention)'가 '의미 있는 행동(significant actions)'으로 '막 옮겨지고 있는' 단계라는 표현도 이를 반영한다. 보다 긍정적인 점은 기업들이 교육, 빈곤퇴치, 고용률, 기후변화와 같은 보다 시급하고 중요한 이슈를 기업 경영 전략에 반영하고 있다는 점이다. 하지만 여전히 글로벌 CSR의 수행이 대기업 위주로 진행되고 
있으며, 하청기업에게 모기업의 규준을 권고, 이를 이행시키는 시스템의 미흡함 또한 지적되고 있다. 이에 비해 한국 기업의 글로벌 CSR 이행 수준은 그 규모의 지속적 증가에도 불구하고 아직 '법규준수' 혹은 '관여(Engaged)' 단계라고 평가되고 있다. 하지만 기부보다는 직접투자 형태의 선호, 글로벌 CSR 수행과 기업의 경쟁력 있는 핵심 업종을 연계시키려는 인식과 노력 또한 두드러지고 있다. 이는 한국 기업의 글로벌 CSR이 향후 전략적 단계로 나갈 수 있는 여지가 마련되고 있음을 보여주고 있는 것이다.

셋째, 현 단계에서 기업의 글로벌 CSR 단계의 정확한 진단과 이를 바탕으로 한 전략형성, 발전 노력이 중요하며, CSV의 추구도 이러한 과정을 전제로 이루어지는 것이 바람직하다. 즉, CSV를 전략적 혹은 혁신(Innovative), 통합(Integrated)적 CSR 단계에서 추구되는 가치형태로 파악하는 것이 중요하며, 이러한 CSR 전략의 기업 내부적 발전과정 없이 유행처럼 도입되는 CSV는 의미있는 기업 전략으로 자리 잡을 수 없음을 인지해야 한다. 개발협력의 관점에서도 구체적인 CSV 전략 추구와 사업형성 고민은 이러한 문제의식과 공감대 위에서 이루어져야 한다.

넷째, 글로벌 CSR의 전략과 기업의 경영전략은 상호 부합해야 한다. 따라서 기업 CSR이 담당 부서에서만 소극적으로 기획, 수행되기 보다는 CSR 전략이 기업의 기획, 생산, 마케팅 과정 등 전반적 활동에 초기에서부터 적극적으로 반영되는 것이 바람직하다. 특히, 전략 형성 측면에서 CSR 활동과 기업의 핵심사업 분야가 연계되어야 한다. 이를 통해 CSR과 기업의 이윤확보가 조화를 이루며 해당 사업이 일회적인 '지원 사업'이 아닌 높은 '지속가능성'을 확보할 수 있다. 개발협력 사업에서도 이러한 연계성이 높은 사업을 지원, 형성하는 것이 사업의 효과성과 지속가능성 측면에서 바람직하다.

다섯째, 글로벌 CSR주체를 민간 기업으로 설정하되, 다양한 형태의 주체 간 조합 형태를 모색할 필요가 있다. CSR-PPP 개념에는 이러한 문제의식이 반영되어 있다. 예를 들어 기존 글로벌 CSR 형태가 기업독자모델 혹은 기업-정부 파트너십 정도에 머물렀다면, 앞으로는 기업-정부-NGO 파트너십, 기업-정부-국제기구-NGO 파트너십 등 보다 다양한 형태가 모색되어야 한다. 즉 사업 성격과 상황에 따라 $\mathrm{NGO}$, 시민사회, 학교, 연구소 등 다양한 주체를 CSR 사업 과정에 적극적으로 포함시켜 그 외연을 확대시켜야 한다. CSV 원리에 바탕을 둔 미국 GDA 사업 등 ODA분야 PPP 성공 사례는 다양한 주체의 재원과 노하우 결합이 개발협력의 효과성을 높일 수 있음을 보여주고 있다.

이러한 결론을 통해 개발협력 사업 형성의 관점에서 다음 몇 가지 시사점이 제안될 수 있다. 첫째, $\mathrm{CSV}$ 의 형성 방법에 대한 정확한 이해와 전 세계적으로 CSV의 성공적 사례를 바탕으로 도출된 원리들은 개발협력의 과정에 유의미하게 적용될 수 있다. 특히, 상품과 시장에 대한 재해석 시각은 시사하는 바가 큰데, 기존 기업들이 관심을 갖지 않았던 '저소득층 니즈 충족형' 제품 생산이나 '지역 소외계층 일자리 창출형“ 사업 개념을 개발협력의 범주에서 적극적으로 해석해야 한다. 가치사슬의 생산성에 대한 재 정의와 이를 통한 CSV 추구 사업도 결국 같은 맥락에서 이해될 수 있다.

둘째, 클러스터 형성을 통한 CSV 실현 방법은 개도국 농촌종합개발 지원 사업, 커뮤니티 비즈니스 개발 사업 등에 적용될 수 있는 모델이 될 수 있다. 따라서 개발협력 사업에서 그 규모와 범위가 
한정되더라도 단위 지역의 농가와 농산물 가공, 유통업체, 생산성 향상과 품질관리 관련 연구소 등이 결합되는 '농촌 공동체 개발형 클러스터 형성' 시범사업과 확대를 고려해 볼 수 있다. 


\section{〈참고문헌〉}

\section{- 국내문헌}

곽재성(2012). 국제개발과 민관협력: 이슈와 정책 제언, 『국제개발협력, 2012년 1호, KOICA

김성규(2012). 사회적 기회와 안전망 확대를 위한 개발협력 방안, KOICA

김성규(2012). 기업의 글로벌 사회적 책임(Global CSR)과 개발협력, 『국제개발협력』, 2012

년 1호, KOICA

김성규(2012). 개도국 민간무분 활성화 ODA 방안: 빈곤층 친화적 시장개발(MM4P)사업을

중심으로, $\mathrm{KOICA}$ 개발정책 포커스 제 16 호, KOICA.

김성규(2011). 사회적기업 연구동향과 주요 이슈, 『사회적 기업과 인적자원전략』, KLI 마이클 포터 지음 ‘ 문휘창 옮김(2009).『마이클 포터의 국가경쟁우위』, 21 세기 북스.

변선영 · 김진욱(2011). 한 · 일기업의 전략적 CSR 활동과 기업성과, 『국제경영연구』, 제 22 권, 제 1 호.

이종서(2010). 유럽연합과 기업의 사회적 책임(CSR): 현황과 전망, 『국제지역연구』, 제 14

권, 제 1 호.

전경련(2013). 사회공헌 백서 2013.

정구현(2008). 한국기업의 글로벌 경영-사례를 통해 본 전략과 시스템, 위즈덤 하우스.

조동성(2009).『2009-2010 IPS 국가경쟁력연구보고서 발표자료』, IPS.

홍성헌(2010). 지속가능경영을 위한 글로벌CSR 전략 및 실천방안, 『임금연구』, 2010 가을호.

홍성헌, 이수형(2009). 한국기업의 글로벌화를 위한 CSR전략에 관한 연구, 『통상정보연구』, 제 11 권 4 호.

\section{- 해외문헌}

Bhattacharya(2008). Korschun(2011), 'Using Corporate Social Responsibility to Win the War for Talent', MIT Sloan Management Review, vol.49, no.2. 
Brown · Dacin(1997). 'The company and the product: corporate associations and consumer product responses', Journal of Marketing, vol. 61, no.1.

Carroll, A. B. (1979). Three Dimensional Conceptual Map of Corporate Performance, “Academy of Management Review" Vol. 4, pp.497-500.

Global Compact(2013). Global Corporate Sustainability Report 2013.

Klaus Schwab(2008). ‘Global Corporate Citizenship’, Foreign Affairs journal Vol 87. No.1.

Porter, M. \& M. Kramer(2006). Strategy and Society: The Link between Competitive Advantage and Corporate Social Responsibility, Harvard Business Review, Vol .84, pp.1-18.

Michael E. Porter and. Mark R. Kramer(2011). Creating Shared Value: How to reinvent capitalism-unleash a wave of innovation and growth, Harvard Business Review, Jan-Feb. 20011, pp.1-17.

Pava · Krausz(1996). 'Corporate Social Responsibility and Financial Performance: the paradox of social cost', Westport, Quorum Books.

Poter and Kramer(2006). 'Strategy \& Society : The Link Between Competitive Advantage and Corporate Social Responsibility', Harvard Business Review, vol. 84 , no. 12 .

Stanwick(1998). "The relationship between corporate social performance and organizational size financial performance and environmental performance: an empirical examination', Journal of Business Ethics, vol. 17.

Wood, D., J. Logsdon. P. Lewellyn, and K. Davenport(2006), Global Business Citizenship: A Transformative Framework for Ethics and Capitalism, M.E. Sharpe.

\section{- 웹사이트}

Corporate Citizenship Center, http://www.bcccc.net/

European Research Network, http://european-research-network.org/ 